Case Report

\title{
A Case of a Laryngeal MALT Lymphoma in a Patient with a History of Gastric MALT
}

\author{
Mark Ashamalla, ${ }^{1}$ Marita S. Teng, ${ }^{2}$ Joshua Brody, ${ }^{3}$ Elizabeth Demicco, ${ }^{4}$ Rahul Parikh, \\ Kavita Dharmarajan, ${ }^{6}$ and Richard L. Bakst ${ }^{6}$ \\ ${ }^{1}$ Sidney Kimmel Medical College at Thomas Jefferson University, Philadelphia, PA 19107, USA \\ ${ }^{2}$ Department of Otolaryngology, Icahn School of Medicine at Mount Sinai Hospital, New York, NY 10029, USA \\ ${ }^{3}$ Department of Medical Oncology, Icahn School of Medicine at Mount Sinai Hospital, New York, NY 10029, USA \\ ${ }^{4}$ Department of Pathology, Icahn School of Medicine at Mount Sinai Hospital, New York, NY 10029, USA \\ ${ }^{5}$ Department of Radiation Oncology, Mount Sinai St. Luke's Roosevelt and Mount Sinai Beth Israel, New York, NY 10029, USA \\ ${ }^{6}$ Department of Radiation Oncology, Icahn School of Medicine at Mount Sinai Hospital, New York, NY 10029, USA
}

Correspondence should be addressed to Richard L. Bakst; richard.bakst@mountsinai.org

Received 21 October 2014; Accepted 20 December 2014

Academic Editor: Marie-Christine Kyrtsonis

Copyright ( 2015 Mark Ashamalla et al. This is an open access article distributed under the Creative Commons Attribution License, which permits unrestricted use, distribution, and reproduction in any medium, provided the original work is properly cited.

We are reporting a case of a 62-year-old African American woman with a history of gastric MALT lymphoma successfully treated with radiation who presented with a laryngeal MALT lymphoma 4 years after her original diagnosis. She received definitive radiation with a complete response. The case presented is unique for the rare presentation of a MALT lymphoma in the larynx, especially in light of the patient's previously treated gastric MALT lymphoma years ago.

\section{Introduction}

Mucosa associated lymphoid tissue lymphomas, or MALT, are extranodal marginal zone B-cell lymphomas. While the most common anatomical location is the stomach, MALT lymphomas can also present in the lung, thyroid, breast, synovium, lacrimal and salivary glands, orbit, dura, skin, and soft tissues [1-13].

Laryngeal MALT lymphomas are exceedingly rare. Our search of the current literature revealed only 27 cases reported between 1990 and 2014 [14-16]. Caletti et al. previously reported a case of a patient with concomitant laryngeal MALT lymphoma and Helicobacter pylori (H. pylori) related gastric MALT lymphoma [17], but to our knowledge, a representation of a MALT lymphoma in the larynx following a gastric MALT lymphoma has never previously been described. Given the rarity of laryngeal MALT lymphomas, the risk factors, prognosis, and optimal management are not well defined.

\section{A Case Report}

In June 2010, a 62-year-old female presented to her gastroenterologist with intermittent epigastric pain for several months. Subsequent endoscopy revealed a gastric lesion. Immunohistochemistry was strongly positive for $\mathrm{CD} 20$ and negative for CD5, CD10, and BCL-6, confirming the diagnosis of MALT lymphoma. Testing was negative for $H$. pylori. Imaging with a PET/CT confirmed a malignancy confined to the stomach with no lymph node avidity or other evidence of disease. $t(11 ; 18)$ status was not performed at the time.

The patient received definitive radiation to her stomach, upper abdomen, and perigastric lymph nodes to a total dose of 3600 cGy at 180 cGy per fraction in 20 fractions over 3 weeks (Figure 1). The patient tolerated treatment well. The patient was followed with serial endoscopies and remained without evidence of disease.

Approximately 4 years following her initial diagnosis, she presented to her gastroenterologist complaining of one year 


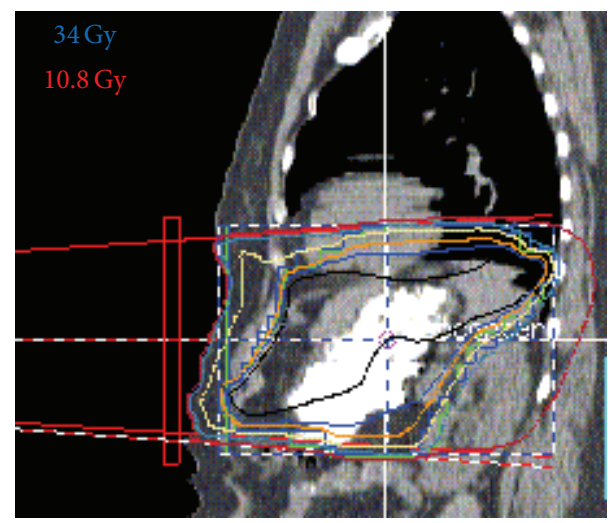

(a)

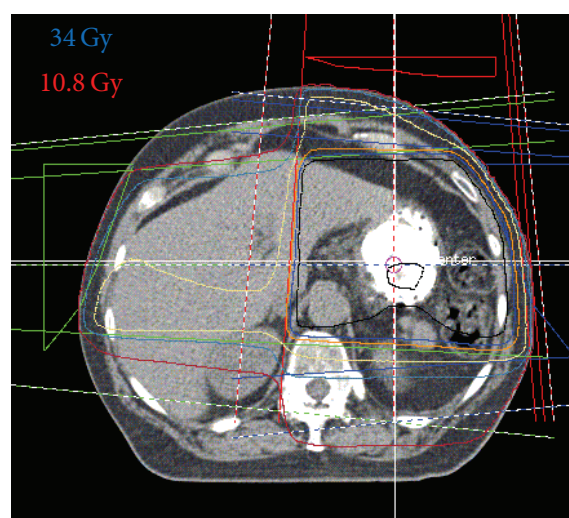

(b)

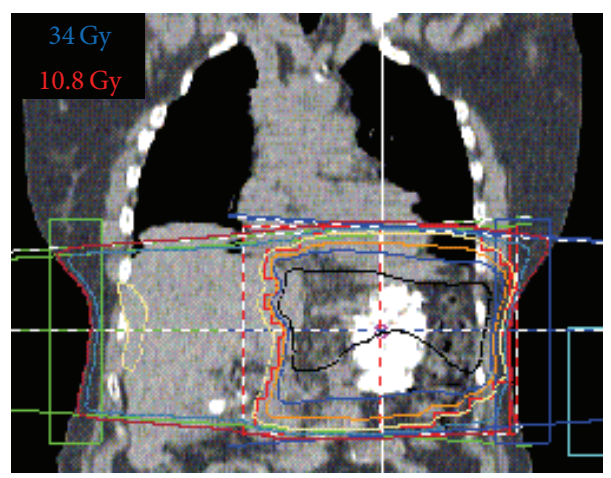

(c)

FIGURE 1: 3D conformal radiation therapy of MALT lymphoma of the stomach. Dose distribution in the saggital (a), axial (b), and coronal (c) planes. Black line represents the 36 Gy isodose line.

of progressive difficulty breathing, dysphagia, odynophagia, and right ear fullness. Subsequent workup with esophagogastroduodenoscopy (EGD) revealed an exophytic, polypoid mass in the right false cord and pyriform sinus.

A fiberoptic examination confirmed a $3 \mathrm{~cm}$ mass arising from the right aryepiglottic fold obscuring view of the right vocal cord (Figure 2(a)). The left vocal cord was minimally visible upon phonation while the vallecula, epiglottis, and pharyngeal wall were spared. Partial involvement of the right pyriform sinus was again noted. PET/CT scan demonstrated avidity only within the laryngeal structures without any evidence of nodal involvement or distant disease (Figure 2(b)). The patient subsequently underwent biopsy of the right supraglottic lesion; pathology was consistent with MALT lymphoma (Figure 2(c)).

The patient received definitive radiation to 3000 cGy in 15 fractions to the larynx and hypopharynx (Figure 3). The patient tolerated the treatment well developing only mild odynophagia and hyperpigmentation of the skin without any breakdown.

At a follow-up visit 1 month after completing treatment, the patient's odynophagia has resolved and she is tolerating a full PO diet. She has also had improvements in her voice.
PET/CT performed 3 months after completing treatment demonstrated a complete resolution of the tumor subsequently (Figure 4), which was confirmed by fiberoptic examination.

\section{Discussion}

Non-Hodgkin lymphomas (NHL) are tumors of the lymphoid tissues, derived from clonal expansion of B cells, $\mathrm{T}$ cells, natural killer (NK) cells, or their precursors. There are over 12 different types of NHL, including diffuse large B cell (31\%), follicular (22\%), and MALT lymphoma (5\%) [26]. MALT lymphomas are considered extranodal marginal zone B-cell lymphomas under the current world health organization classification system.

MALT lymphomas have been associated with immune system dysregulation from autoimmune disorders like Sjogren's syndrome [27] or sustained immune stimulation from chronic infections with Chlamydia psittaci, Campylobacter jejuni, and Borrelia burgdorferi [28]. In the stomach, they are most commonly associated with chronic infection with Helicobacter pylori $[29,30]$. While information on a prognostic parameter such as $\mathrm{LDH}$ would be helpful, it was unavailable 


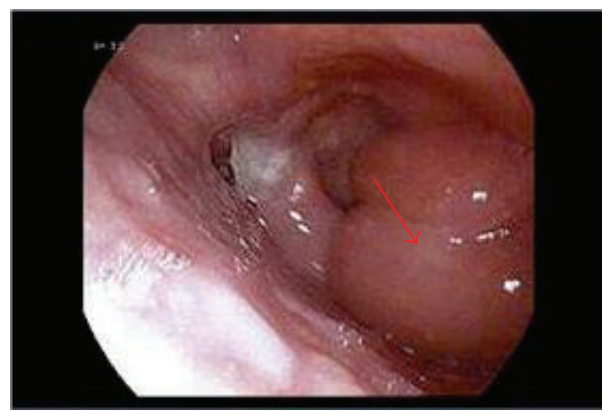

(a)
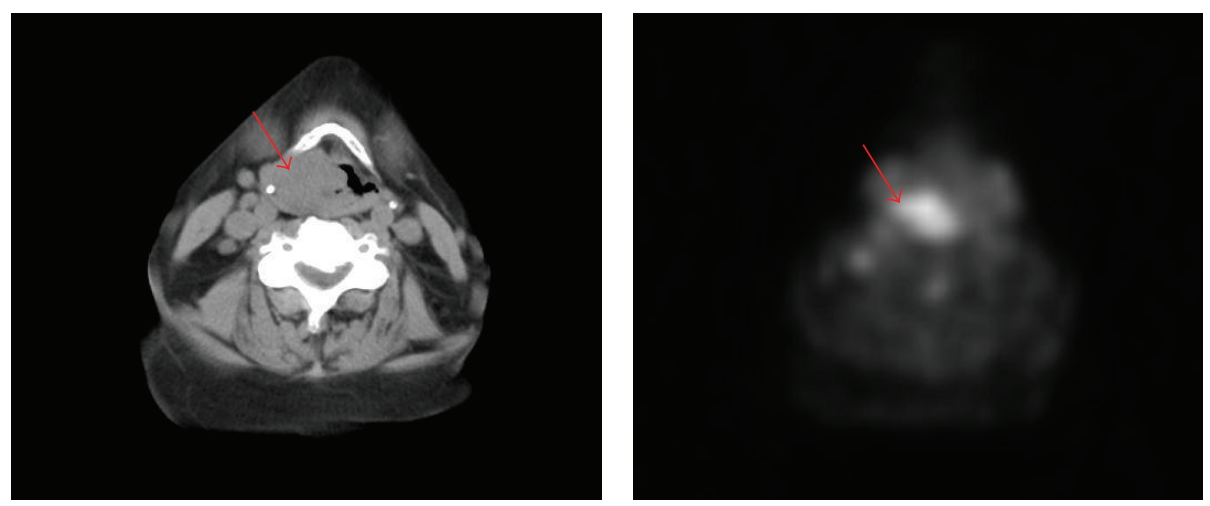

(b)
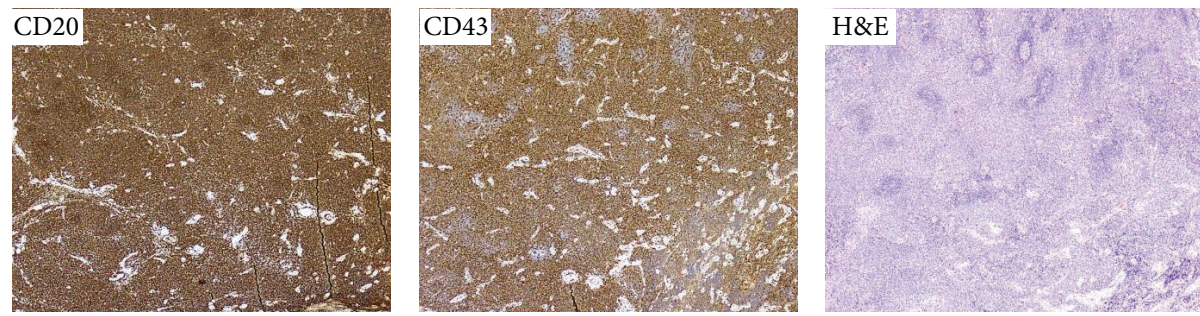

(c)

FIGURE 2: Laryngeal MALT lymphoma. (a) A $3 \mathrm{~cm}$ mass arising from the right aryepiglottic fold obscuring view of the right vocal cord on fiberoptic examination (red arrow). (b) PET/CT demonstrates a PET-avid exophytic mass arising from the right false cord (red arrow). (c) Immunohistochemistry: high power view (40x) anti-CD20, anti-CD43, and H\&E: dense lymphocytic infiltrate and scattered small reactiveappearing follicles are seen surrounded by diffuse sheets of neoplastic marginal zone cells.

from an outside institution. Interestingly, our patient had neither a history of autoimmune disease nor an infection with the previously mentioned pathogens.

Radiation therapy represents a definitive treatment option for MALT lymphoma in patients with localized disease. For gastric MALT lymphomas, without $t(11 ; 18)$ status, antibiotics may not have been first line therapy. A radiotherapy regimen of $30 \mathrm{~Gy}$ in 20 fractions to the stomach and perigastric nodes has previously been reported with excellent clinical outcomes with high rates of pathological complete responses [31]. In 2013, Zucca et al. presented the ESMO Clinical Practice Guidelines for diagnosis, treatment, and follow-up, reporting excellent disease control with RT alone using moderate-dose involved-field radiotherapy using 24$30 \mathrm{~Gy}$ to the stomach and perigastric nodes given in 3 to 4 weeks [32]. In its most recent guidelines released in 2014, the International Lymphoma Radiation Oncology Group reports its consensus on target definition and dose prescriptions for nodal non-Hodgkin lymphoma. There is a move away from previously applied extended-field and involved-field RT (IFRT) techniques that targeted nodal regions toward limiting the RT to smaller volumes based solely on detectable nodal involvement at presentation or involved-site RT (ISRT) as the clinical target volume [33]. Both presentations of this patient were treated using 3D conformal IFRT technique in which the entire organ (larynx or stomach) was treated.

The presentation of laryngeal MALT lymphomas is exceedingly rare, with less than 30 previously reported cases in the literature. Of the previously reported cases, only 11 have involved the supraglottic larynx. These lymphomas are highly radiosensitive. For localized disease, radiotherapy is the most appropriate treatment for larynx preservation. Chemotherapy is reserved for recurrent or disseminated disease [34]. The prognosis is generally favorable with some 


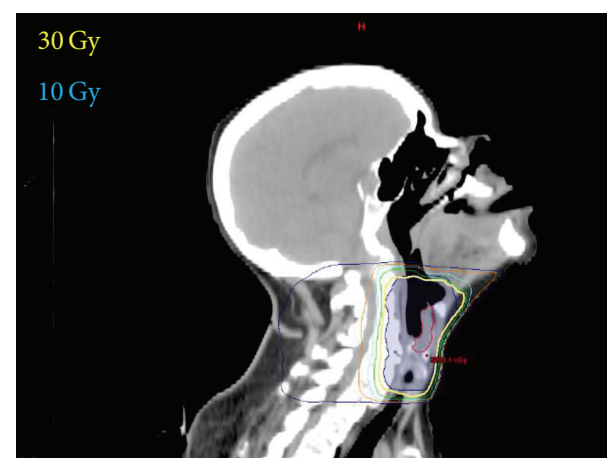

(a)

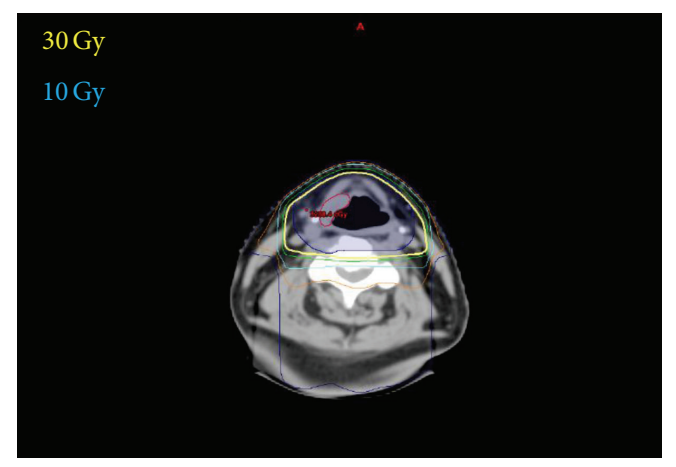

(b)

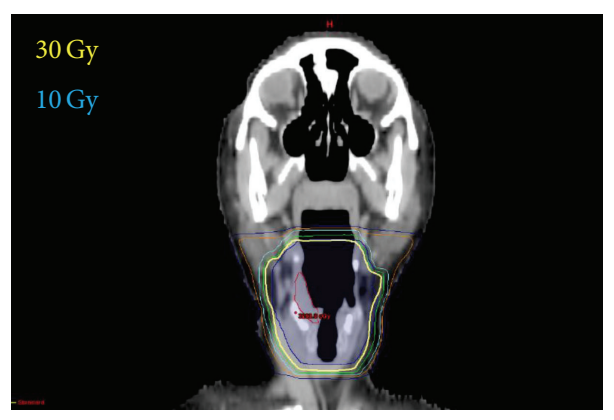

(c)

FIGURE 3: 3D conformal radiation therapy of MALT lymphoma of the larynx. Dose distribution in the saggital (a), axial (b), and coronal (c) planes. Yellow line represents the $30 \mathrm{~Gy}$ isodose line.

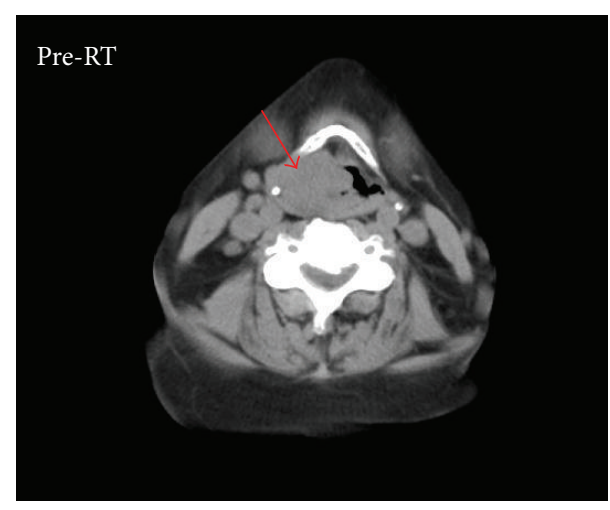

(a)

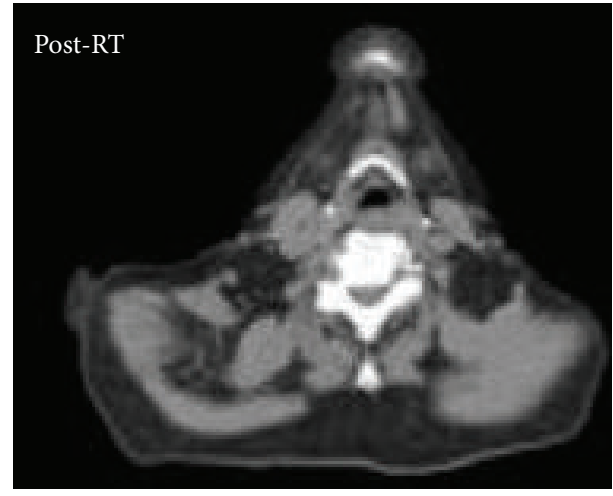

(b)

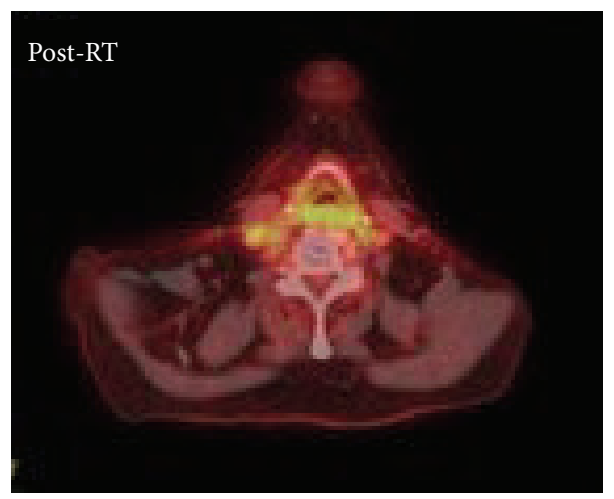

(c)

FIGURE 4: Complete response following radiation therapy. The mass (red arrow) present on CT-based imaging performed at diagnosis (a) has resolved 3 months following radiation (b) and there is no corresponding PET avidity (c). 
TABLE 1: Characteristics of the English-language reported cases of supraglottic laryngeal lymphomas from 1997 to 2014.

\begin{tabular}{|c|c|c|c|c|c|c|}
\hline Study & Age at presentation & Gender & $\begin{array}{l}\text { Symptoms at } \\
\text { presentation }\end{array}$ & Treatment & Disease status & $\begin{array}{l}\text { Follow-up } \\
(\mathrm{mo})\end{array}$ \\
\hline Zhao et al., 2012 [15] & 35 & $\mathrm{~F}$ & Hoarseness & 2 cycles $\mathrm{CHOP}, 27 \mathrm{~Gy}$ & NED & 3 \\
\hline Markou et al., 2010 [18] & 67 & M & $\begin{array}{l}\text { Hoarseness, } \\
\text { stridor, dyspnea }\end{array}$ & Immediate tracheostomy, CHOP & NED & 48 \\
\hline Gonzàlez et al., 2009 [19] & 42 & $\mathrm{~F}$ & $\begin{array}{l}\text { Cough, } \\
\text { dysphonia }\end{array}$ & RT & NED & 96 \\
\hline Arndt et al., 2007 [20] & 34 & $\mathrm{~F}$ & Hoarseness & Doxycycline, FCR regimen & NED & 6 \\
\hline Fujita et al., 2007 [21] & 64 & M & Hoarseness & CHOP-R & NED & 18 \\
\hline Kania et al., 2005 [22] & 46 & M & Dysphonia & $\begin{array}{c}\mathrm{Co}_{2} \text { laser excision, Omeprazole, } \\
\text { Amoxicillin, Clarithromycin }\end{array}$ & NED & 24 \\
\hline Caletti et al., 2003 [17] & 57 & M & Hoarseness & Anti-H. pylori therapy & NED & 46 \\
\hline Cheng et al., 1999 [23] & 58 & $\mathrm{~F}$ & $\begin{array}{l}\text { Hoarsness and } \\
\text { foreign body } \\
\text { sensation }\end{array}$ & 30 Gy & NED & 12 \\
\hline de Bree et al., 1998 [24] & 36 & $\mathrm{~F}$ & Hoarseness & Debulking and $28 \mathrm{~Gy}$ & NED & 24 \\
\hline Kato et al., 1997 [25] & 54 & $\mathrm{~F}$ & Dysphonia & $\begin{array}{c}\text { CHOP and RT, lung: surgery and } \\
\text { RT }\end{array}$ & NED & 35 \\
\hline
\end{tabular}

CHOP: cyclophosphamide, hydroxydaunorubicin, vincristine, prednisone.

CHOP-R: cyclophosphamide, hydroxydaunorubicin, vincristine, prednisone, rituximab.

FCR: fludarabine, cyclophosphamide, rituximab.

NED: no evidence of disease.

SOB: shortness of breath.

mo: months.

RT: radiotherapy.

Gy: gray.

cases showing no evidence of disease up to 96 months after treatment (Table 1).

The larynx, which has little lymphoid tissue, may be involved secondarily in cases of disseminated malignant lymphoma; therefore clinical staging before and after treatment is necessary [34]. When considering radiation as monotherapy, staging becomes of paramount importance. ${ }^{18}$ F-FDG PET/CT has been used for staging laryngeal MALT lymphomas and has provided a basis for both altering the therapeutic strategy and also evaluating the response to radiotherapy [15]. However, despite being proven valuable in detecting sites of disease in some types of lymphomas, ${ }^{18} \mathrm{~F}$-FDG PET/CT is not yet the standard method of staging and cannot substitute bone marrow examination. Biopsies from the ileum could add information as to the extent of this patient's initial disease. It could also explain the fact that the lymphoma which was treated with local therapy relapsed in another extranodal site. The above could be also addressed after the representation and give important information for this case.

In conclusion, laryngeal MALT lymphomas represent rare clinical entities without any clear risk factors. For early stage disease, definitive radiation to a low dose represents an excellent treatment option with limited morbidity, excellent functional outcome, and durable disease control.

\section{Conflict of Interests}

The authors have no actual or potential conflict of interests.

\section{References}

[1] M. F. Rosado, G. E. Byrne Jr., F. Ding et al., "Ocular adnexal lymphoma: a clinicopathologic study of a large cohort of patients with no evidence for an association with Chlamydia psittaci," Blood, vol. 107, no. 2, pp. 467-472, 2006.

[2] E. Zucca, A. Conconi, E. Pedrinis et al., "Nongastric marginal zone B-cell lymphoma of mucosa-associated lymphoid tissue," Blood, vol. 101, article 2489, 2003.

[3] R. W. Tsang, M. K. Gospodarowicz, M. Pintilie et al., "Stage I and II malt lymphoma: results of treatment with radiotherapy," International Journal of Radiation Oncology Biology Physics, vol. 50, no. 5, pp. 1258-1264, 2001.

[4] F. M. Iwamoto, L. M. DeAngelis, and L. E. Abrey, "Primary dural lymphomas: a clinicopathologic study of treatment and outcome in eight patients," Neurology, vol. 66, no. 11, pp. 1763$1765,2006$.

[5] P. H. Tu, C. Giannini, A. R. Judkins et al., "Clinicopathologic and genetic profile of intracranial marginal zone lymphoma: a primary low-grade CNS lymphoma that mimics meningioma," Journal of Clinical Oncology, vol. 23, no. 24, pp. 5718-5727, 2005.

[6] A.-C. George, M. Ozsahin, R. Janzer et al., "Primary intracranial dural lymphoma of mucosa-associated lymphoid tissue (MALT) type: report of one case and review of the literature," Bulletin du Cancer, vol. 92, no. 7, pp. E51-E56, 2005.

[7] J. S. Welsh, A. Howard, H. Y. Hong, D. Lucas, T. Ho, and D. J. Reding, "Synchronous bilateral breast mucosa-associated lymphoid tissue lymphomas addressed with primary radiation therapy," American Journal of Clinical Oncology, vol. 29, no. 6, pp. 634-635, 2006. 
[8] J. I. Ikeda, E. Moni, A. Yamauchi et al., "Extranodal marginal zone B-cell lymphoma of mucosa-associated lymphoid tissue type developing in gonarthritis deformans," Journal of Clinical Oncology, vol. 25, no. 27, pp. 4310-4312, 2007.

[9] O. Servitje, F. Gallardo, T. Estrach et al., "Primary cutaneous marginal zone B-cell lymphoma: a clinical, histopathological, immunophenotypic and molecular genetic study of 22 cases," British Journal of Dermatology, vol. 147, no. 6, pp. 1147-1158, 2002.

[10] J. A. Ferry, C. Y. Fung, L. Zukerberg et al., "Lymphoma of the ocular adnexa: a study of 353 cases," The American Journal of Surgical Pathology, vol. 31, no. 2, pp. 170-184, 2007.

[11] A. Stefanovic and I. S. Lossos, "Extranodal marginal zone lymphoma of the ocular adnexa," Blood, vol. 114, no. 3, pp. 501510, 2009.

[12] M. Troch, M. Formanek, B. Streubel, L. Müllauer, A. Chott, and M. Raderer, "Clinicopathological aspects of mucosa-associated lymphoid tissue (MALT) lymphoma of the parotid gland: a retrospective single-center analysis of 28 cases," Head \& Neck, vol. 33, no. 6, pp. 763-767, 2011.

[13] M. O. Khalil, L. M. Morton, S. S. Devesa et al., "Incidence of marginal zone lymphoma in the United States, 2001-2009 with a focus on primary anatomic site," British Journal of Haematology, vol. 165, no. 1, pp. 67-77, 2014.

[14] M. A. Tunio, M. AlAsiri, A. M. Maklad, and Y. Bayoumi, "Clinicopathological features and treatment outcomes of primary thyroid lymphomas in Saudi Arabia: a case series of seven patients," Cancer Treatment Communications, vol. 1, no. 1, pp. $14-17,2013$.

[15] K. Zhao, Y. Z. Luo, S. H. Zhou et al., "18 F-fluorodeoxyglucose positron emission tomography/computed tomography findings in mucosa-associated lymphoid tissue lymphoma of the larynx: a case report and literature review," Journal of International Medical Research, vol. 40, no. 3, pp. 1192-1206, 2012.

[16] C. Bielinski, H. S. Luu, and T. Mau, "Mucosa-associated lymphoid tissue (MALT) lymphoma presenting as subglottic stenosis: single-agent treatment using rituximab," OtolaryngologyHead and Neck Surgery, vol. 150, no. 2, pp. 334-335, 2014.

[17] G. Caletti, T. Togliani, P. Fusaroli et al., "Consecutive regression of concurrent laryngeal and gastric MALT lymphoma after antiHelicobacter pylori therapy," Gastroenterology, vol. 124, no. 2, pp. 537-543, 2003.

[18] K. Markou, J. Goudakos, J. Constantinidis, I. Kostopoulos, V. Vital, and A. Nikolaou, "Primary laryngeal lymphoma: report of 3 cases and review of the literature," Head and Neck, vol. 32, no. 4, pp. 541-549, 2010.

[19] N. Gonzàlez, B. Xicoy, A. Olivé, J. Jové, J.-M. Ribera, and E. Feliu, "Systemic lupus erythematosus in a patient with primary MALT lymphoma of the larynx," Ear, Nose and Throat Journal, vol. 88, no. 8, pp. E4-E5, 2009.

[20] S. Arndt, H. Veelken, A. Schmitt-Gräff, A. Aschendorff, W. Maier, and B. Richter, "Multifocal extranodal mucosaassociated lymphoid tissue lymphoma affecting the larynx," Annals of Otology, Rhinology and Laryngology, vol. 116, no. 4, pp. 257-261, 2007.

[21] A. Fujita, H. Sugimoto, O. Sakai, H. Tanaka, T. Matsuyama, and A. Tanaka, "Mucosa-associated lymphoid tissue (MALT) lymphoma of the larynx: a case report with MR imaging findings," European Journal of Radiology Extra, vol. 62, no. 3, pp. 69-72, 2007.

[22] R. E. Kania, D. M. Hartl, C. Badoual, C. Le Maignan, and D. F. Brasnu, "Primary mucosa-associated lymphoid tissue (MALT) lymphoma of the larynx," Head and Neck, vol. 27, no. 3, pp. 258262, 2005.

[23] C.-J. Cheng, P.-R. Chen, M.-C. Liu, M.-S. Kuo, and Y.-H. Hsu, "Primary malignant lymphoma of mucosa-associated lymphoid tissue of larynx," Otolaryngology-Head and Neck Surgery, vol. 121, no. 5, pp. 661-662, 1999.

[24] R. de Bree, H. F. Mahieu, G. J. Ossenkoppele, and P. van der Valk, "Malignant lymphoma of mucosa-associated lymphoid tissue in the larynx," European Archives of Oto-Rhino-Laryngology, vol. 255, no. 7, pp. 368-370, 1998.

[25] S. Kato, M. Sakura, S. Takooda, M. Sakurai, and T. Izumo, "Primary non-Hodgkin's lymphoma of the larynx," The Journal of Laryngology \& Otology, vol. 111, no. 6, pp. 571-574, 1997.

[26] J. O. Armitage and D. D. Weisenburger, "New approach to classifying non-Hodgkin's lymphomas: clinical features of the major histologic subtypes," Journal of Clinical Oncology, vol. 16, no. 8, pp. 2780-2795, 1998.

[27] K. E. Smedby, E. Baecklund, and J. Askling, "Malignant lymphomas in autoimmunity and inflammation: a review of risks, risk factors, and lymphoma characteristics," Cancer Epidemiology, Biomarkers \& Prevention, vol. 15, no. 11, pp. 2069-2077, 2006.

[28] R. J. Bende, F. van Maldegem, and C. J. M. van Noesel, "Chronic inflammatory disease, lymphoid tissue neogenesis and extranodal marginal zone B-cell lymphomas," Haematologica, vol. 94, no. 8, pp. 1109-1123, 2009.

[29] J. H. Yi, S. J. Kim, J. Y. Choi, Y. H. Ko, B. T. Kim, and W. S. Kim, ${ }^{~} 18$ F-FDG uptake and its clinical relevance in primary gastric lymphoma," Hematological Oncology, vol. 28, no. 2, pp. 57-61, 2010.

[30] E. J. Beswick, G. Suarez, and V. E. Reyes, "H. pylori and host interactions that influence pathogenesis," World Journal of Gastroenterology, vol. 12, no. 35, pp. 5599-5605, 2006.

[31] N. R. Schechter, C. S. Portlock, and J. Yahalom, "Treatment of mucosa-associated lymphoid tissue lymphoma of the stomach with radiation alone," Journal of Clinical Oncology, vol. 16, no. 5, pp. 1916-1921, 1998.

[32] E. Zucca, C. Copie-Bergman, U. Ricardi, C. Thieblemont, M. Raderer, and M. Ladetto, "Gastric marginal zone lymphoma of MALT type: ESMO clinical practice guidelines for diagnosis, treatment and follow-up," Annals of Oncology, vol. 24, no. 6, pp. vil44-vil48, 2013.

[33] T. Illidge, L. Specht, J. Yahalom et al., "Modern radiation therapy for nodal non-hodgkin lymphoma-target definition and dose guidelines from the international lymphoma radiation oncology group," International Journal of Radiation Oncology Biology Physics, vol. 89, no. 1, pp. 49-58, 2014.

[34] N. A. Siddiqui, B. F. Branstetter IV, B. E. Hamilton et al., "Imaging characteristics of primary laryngeal lymphoma," The American Journal of Neuroradiology, vol. 31, no. 7, pp. 1261-1265, 2010. 


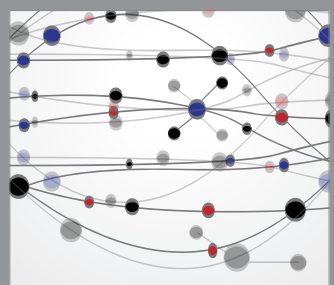

The Scientific World Journal
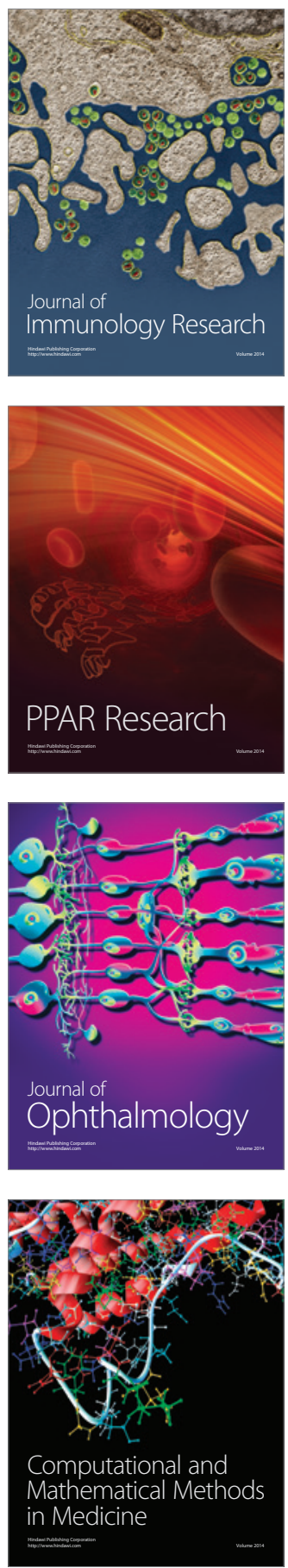

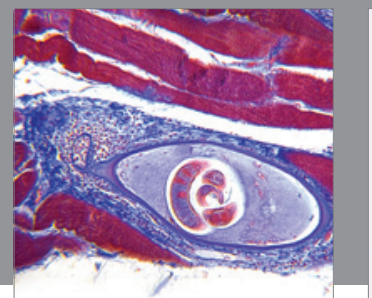

Gastroenterology

Research and Practice
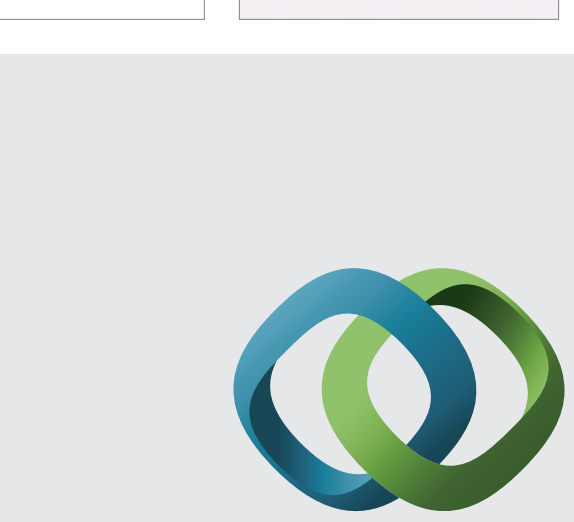

\section{Hindawi}

Submit your manuscripts at

http://www.hindawi.com
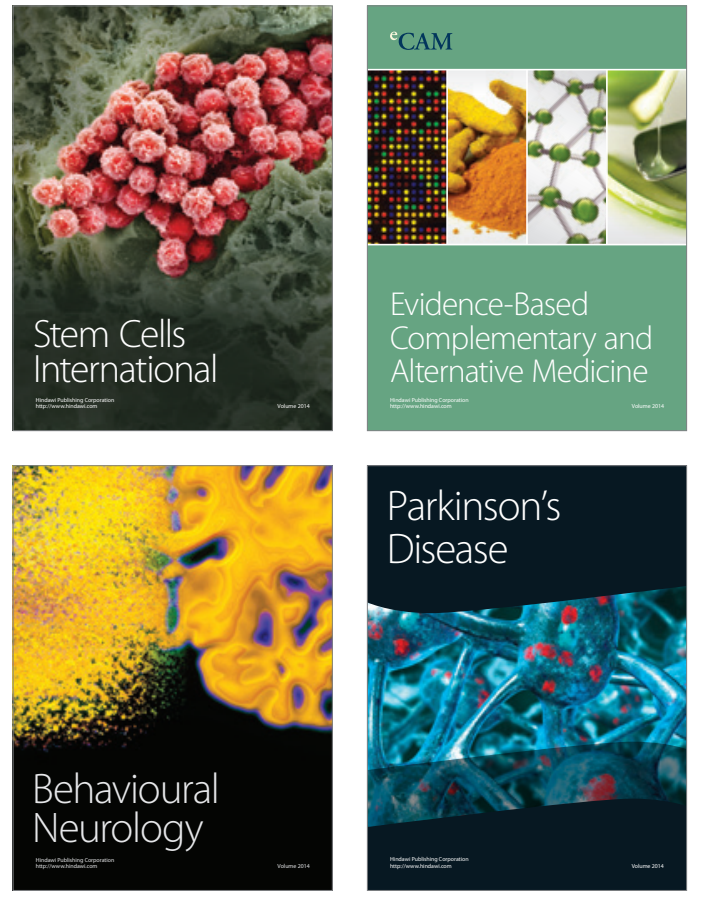
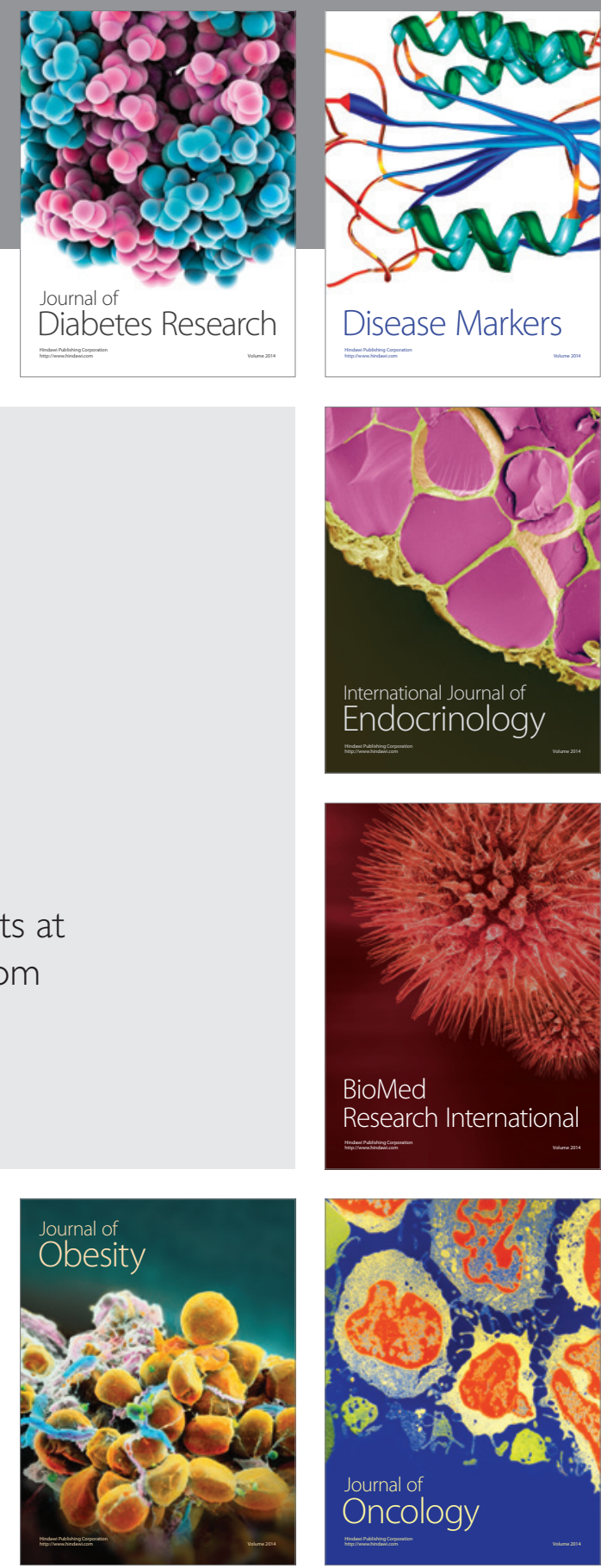

Disease Markers
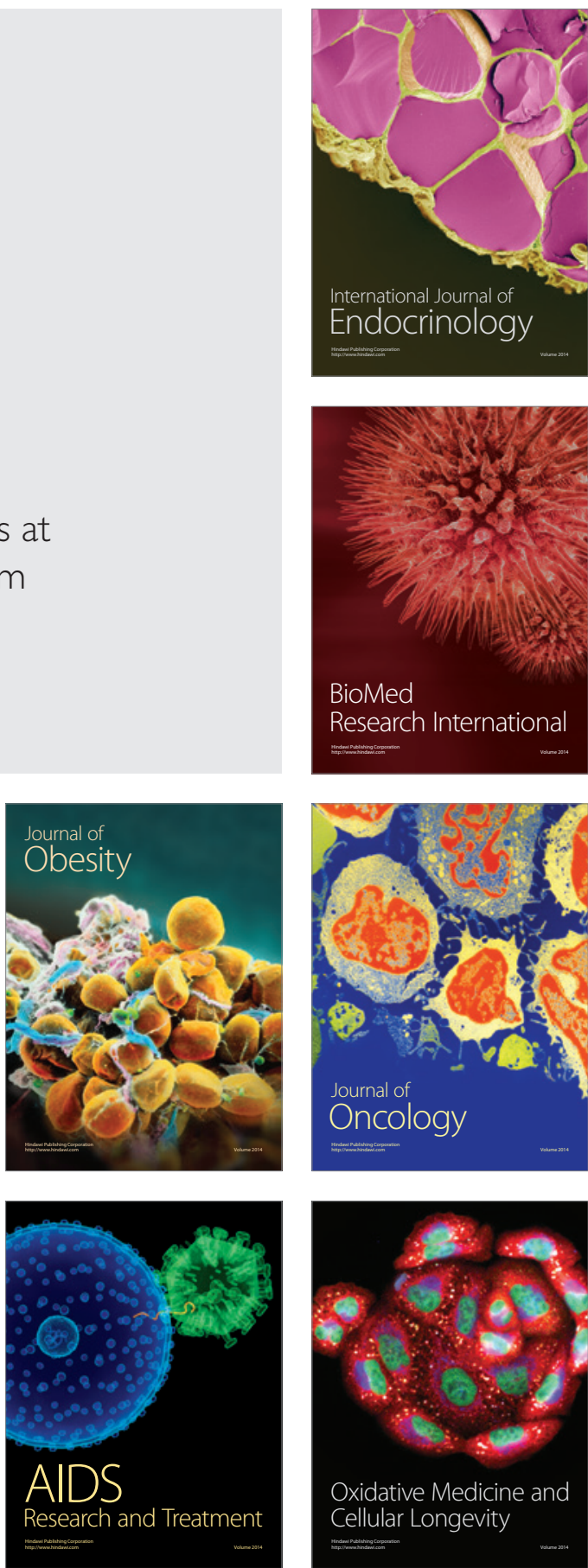